\title{
Analysis of Tunnel Form Building Retrofitted with CFRP using Finite Element Method
}

\author{
Mahmoud Ziada1, Sertaç Tuhta1, Eren Hayati Gençbay¹, Furkan Günday¹, Yosra Tammam²
}

${ }_{1}^{1}$ Department of Civil Engineering, Ondokuz Mayis University, Faculty of Engineering, Atakum/Samsun, Turkey 2İstanbul University, Faculty of Engineering, Department of Civil Engineering, Avcllar/İstanbul, Turkey

\begin{abstract}
Many regions where have the earthquake risk around the world, many buildings in developing countries are ineffective in front of earthquake forces. Recent years, the fabrics which are strengthening with carbon fiber-reinforced polymer (CFRP) have become a very common material to strengthen the reinforced concrete buildings. In our country, mostly column jacketing and partition systems are used. They are also followed with steel jacketing and trussed steel joist systems. Reinforcement with composites named FRP (fiber-reinforced polymer) are getting common slowly by slowly in our country. Since fibers are hightensile steel, they increase the strength of joist and covering deflection. If it is used in the direction of tensile, it also saves the strength for shearing. In this study, $1 \mathrm{~mm}$ CFRP hardware is applied to the each covering of a 16-floor reinforced concrete building which is made with tunnel formwork system. In this analysis done with SAP2000 program, increase in the frequency of a reinforced concrete building is observed; structure which has less in cycle is appeared. These results show us that CFRP hardware's make and \%38 increase in the rigid of structure.
\end{abstract}

Keywords: Frequency; CFRP, FRP; SAP2000, MOD

\section{INTRODUCTION}

Most of the structures found in earthquake hazardous areas are subject to various destructive effects caused by seismic loads. When an earthquake occurs, the structural elements of the structures are damaged. On the other hand, especially considering the performance of structures in seismic load effect, it is very important to strengthen the columns without changing the mass of the building. It is clear that this technique needs to investigate the relationship between repair and retrofitting operations and column capacity. More work should be done to clarify the performance of structures under seismic loads. Recently, application of fiber reinforced plastic composite system by gluing them to external part of the reinforced concrete structures is gradually becoming popular for the aim of repairing and strengthening (Yang et al. 2017), Keykha (2017), (Smyrou et al. 2015), Elwan and Omar (2014). Fibers to be used, as they have required characteristics include: glass, aramid and carbon. The production of these fibers is done in two ways: either as plates (covered by thin fibers) or as tissues (knitted in one and two directions). The behavior of the system that is covered with external FRP composite is related to the type of the element covered. Generally, FRPs have been separated into three categories: bending strengthening, shear strengthening and envelope scripts. The experimental result shows that CFRP laminate can effectively be used to provide beams ductility performance. The effect of FRP wrapping number to the maximum axial capacity has been evaluated Kasimzade and Tuhta (2012), Kasimzade and Tuhta (2017), Kasimzade and Tuhta (2005).

\section{BUILDING DESCRIPTION}

The tunnel form building consists of 16 stories with shear walls. The building was used as an apartment. The height of the stories is 3 meters, and the total height of the building is 48 meters. The floor of the building is 22,15 meter from XZ and 23,6 meter from YZ.

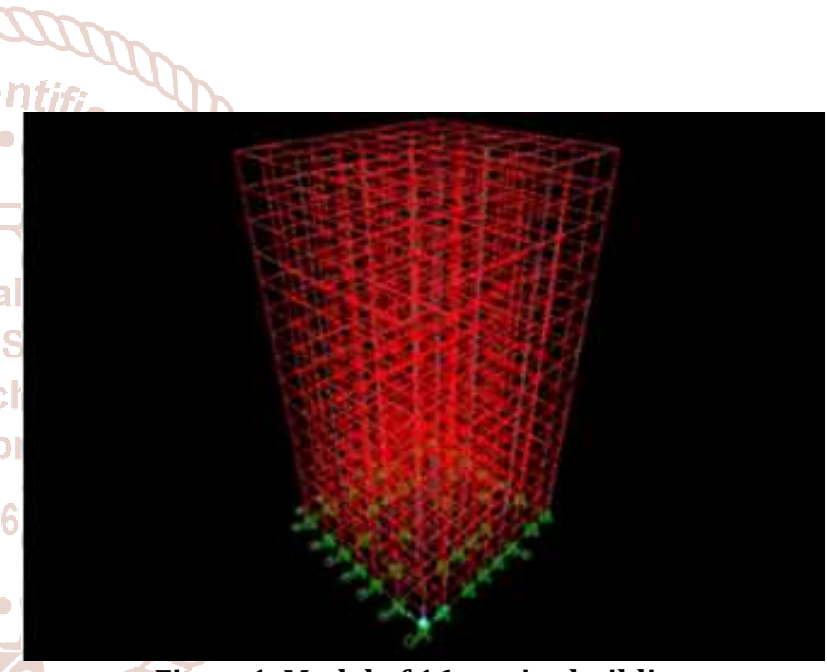

Figure1. Model of 16 stories building

\section{ANALYSIS \& COMPARISON}

Using SAP2000 program CFRP's properties and existing Masonry building model's loads and materials properties were entered.

A. Modal Periods and Frequencies Comparison The modal frequency \& periods before \& after the application of unidirectional CFRP are given in table 1 and table 2 .

Table1. Modal periods and frequencies (existing building)

\begin{tabular}{|c|c|c|c|}
\hline Case & Mode & Period (sec) & Frequency (cyc/sec) \\
\hline Modal & 1 & 1.654946 & 0.60425 \\
\hline Modal & 2 & 1.132158 & 0.88327 \\
\hline Modal & 3 & 1.041482 & 0.96017 \\
\hline
\end{tabular}

Table2. Modal periods and frequencies (retrofitted building)

\begin{tabular}{|c|c|c|c|}
\hline Case & Mode & Period (sec) & Frequency (cyc/sec) \\
\hline Modal & 1 & 1.196734 & 0.83561 \\
\hline Modal & 2 & 0.927908 & 1.07770 \\
\hline Modal & 3 & 0.882561 & 1.13310 \\
\hline
\end{tabular}



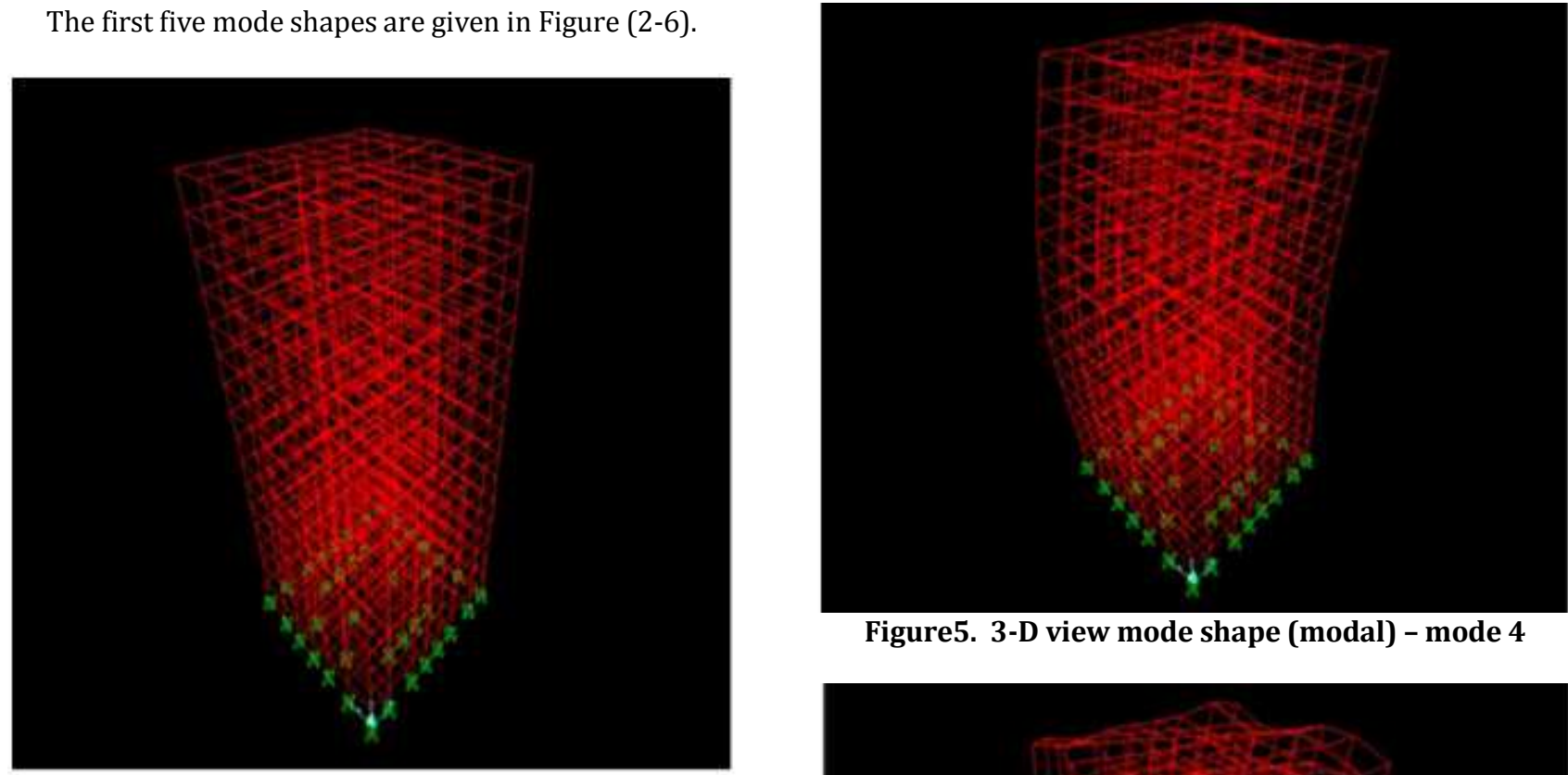

Figure5. 3-D view mode shape (modal) - mode 4

Figure2. 3-D view mode shape (modal) - mode 1

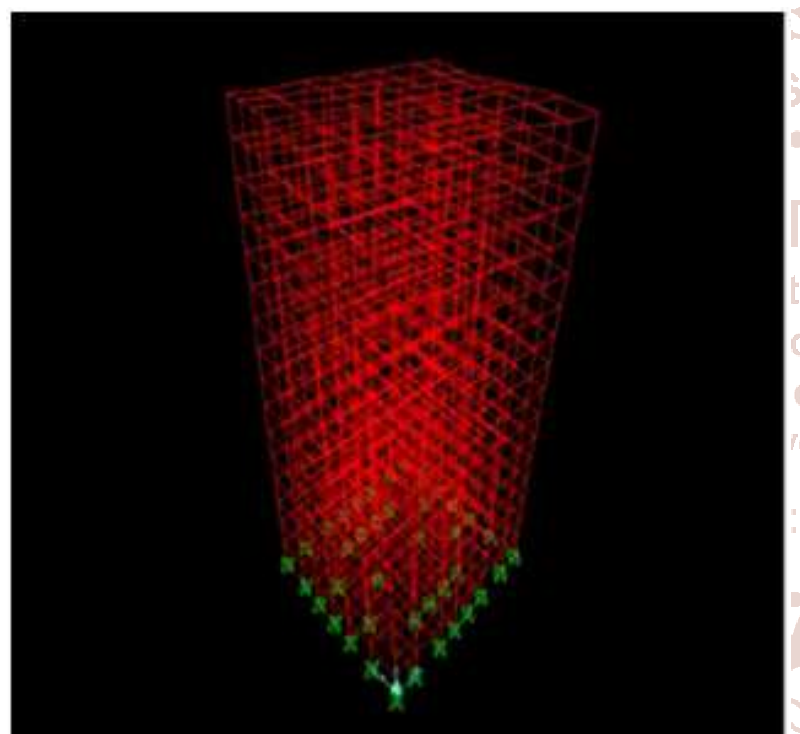

Figure3. 3-D view mode shape (modal) - mode 2

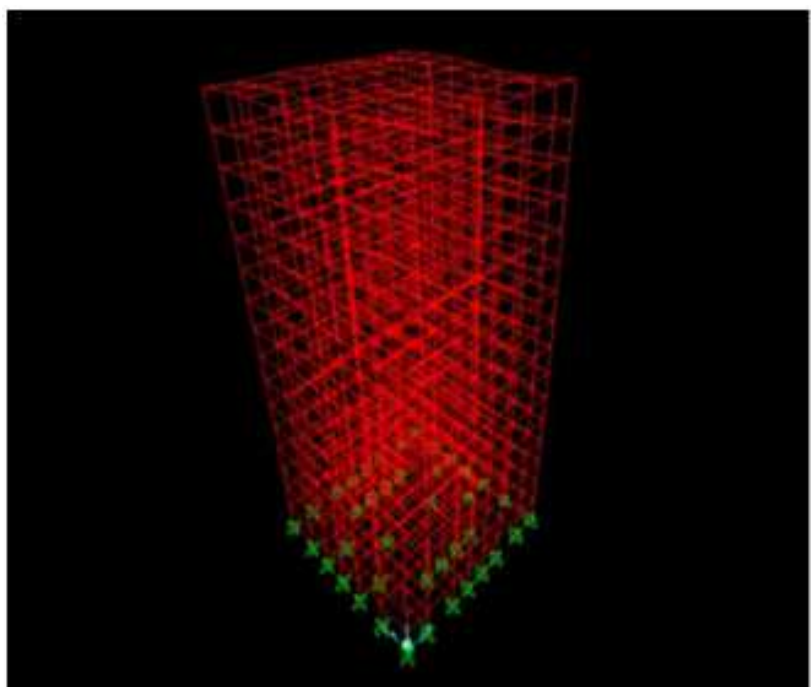

Figure4. 3-D view mode shape (modal) - mode 3

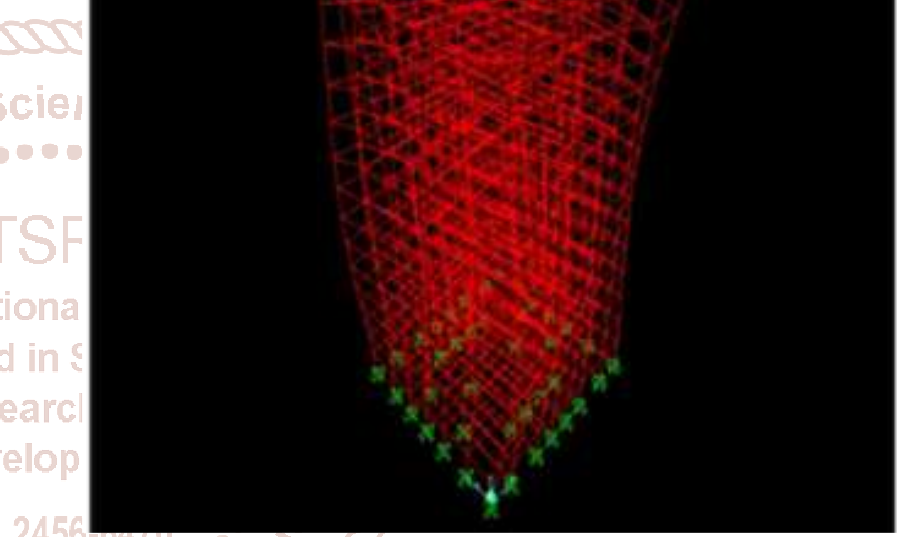

Figure6. 3-D view mode shape (modal) - mode 5

\section{B. Maximum Moment and Maximum Shear Force Comparison}

Using SAP2000 program moment and maximum shear force impacts were shown when CFRP materials were added to the slap of the existing building and the effect was visually illustrated in the left side of the underlying shapes. Maximum moment and maximum shear force effect before the application of CFRP materials to the slap of the existing building are visually illustrated in the right side of the underlying shapes. By looking at these illustrations, the differences can be seen clearly. Figure (7-10).

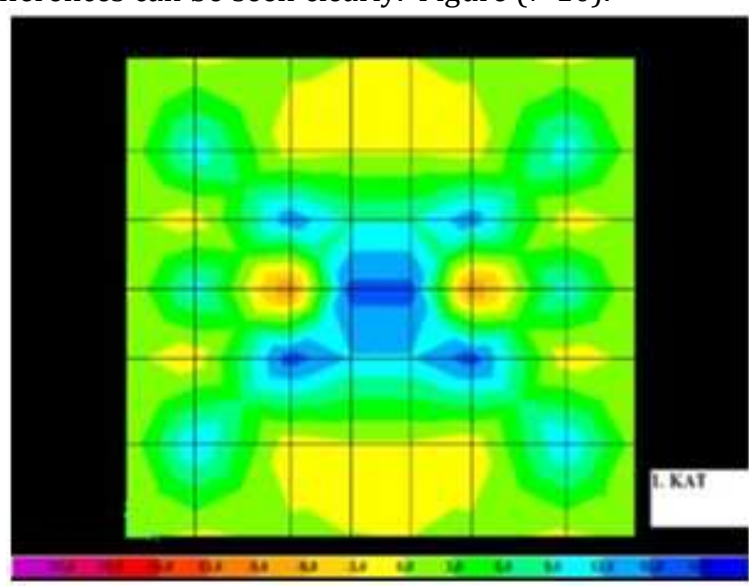

Existing building 


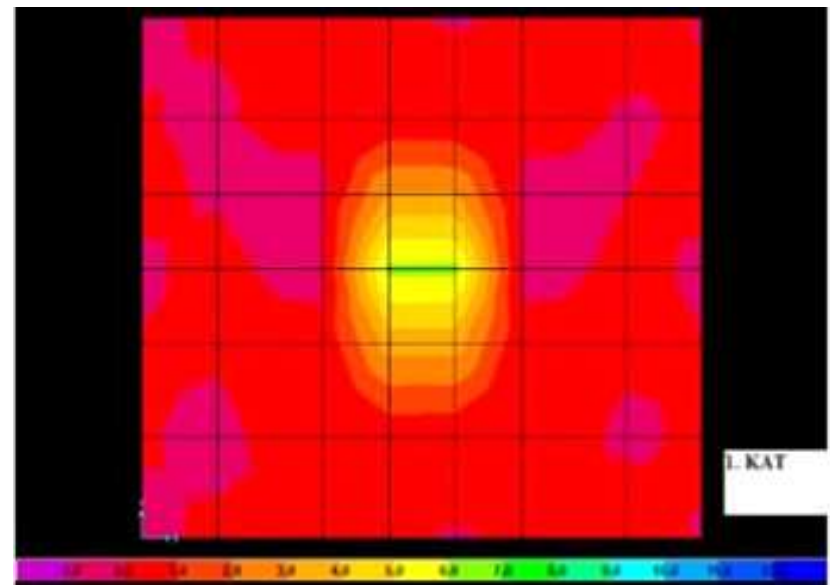

Figure7. M max diagram (storey 1)

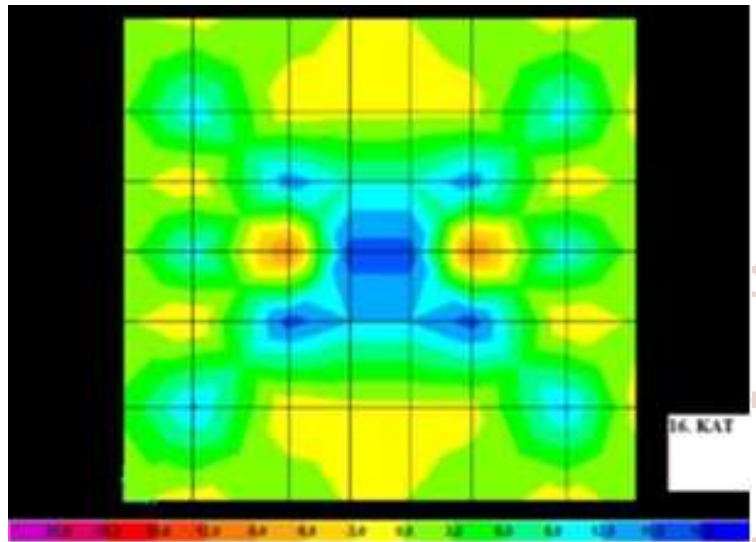

Existing building

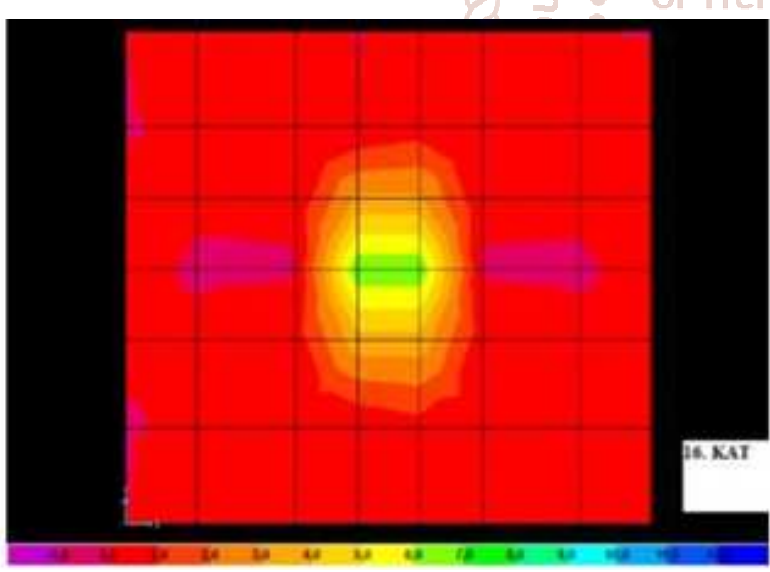

Retrofitted building

Figure8. M max diagram (storey 16)

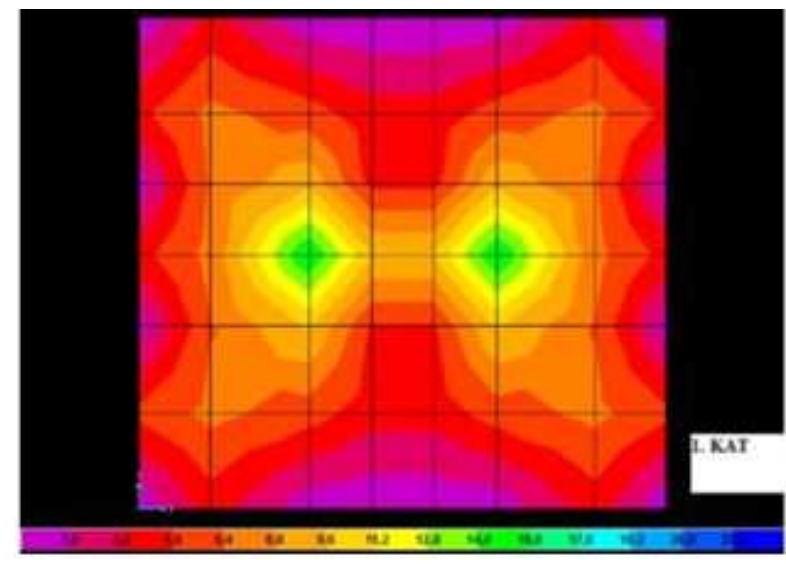

Existing building

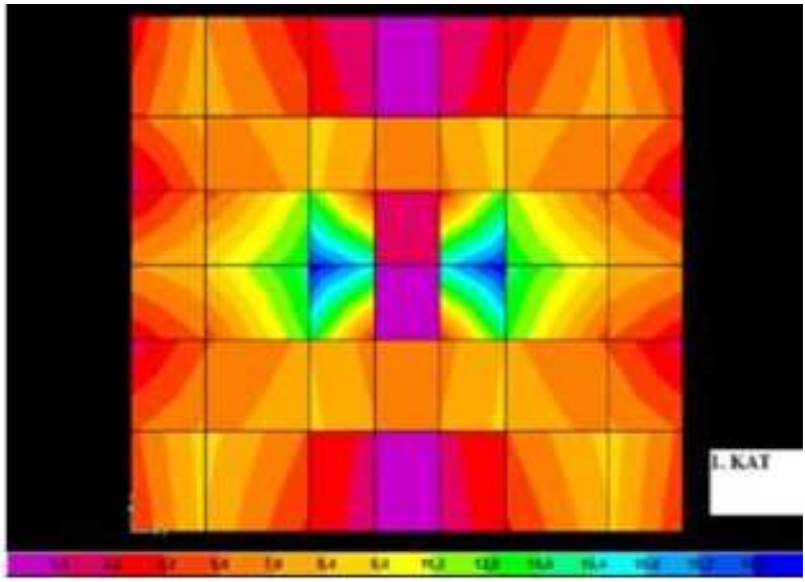

Retrofitted building

Figure9. V max diagram (storey 1)

Figs. 1 shows the effect of frequency on the imaginary part of the dielectric study the dielectric loss (") increases from 0.2 (at $15 \mathrm{~Hz}$ ) attains a maxima of 0.8 (about 300 $\mathrm{Hz}$ ) in lower frequency range and in case of higher frequency range 0.2 (at $500 \mathrm{kHz}$ ) and $\sim 1.0$ at $40 \mathrm{C}-$ for sample SCE-4 .

At higher frequencies, second loss peak have been observed. It is expected to have been formed the other relaxation mode. We believe that the other relaxation mode originates as a consequence of surface effects due to the charge accumulation phenomena between the alignment layer and the ferroelectric liquid crystal materials.
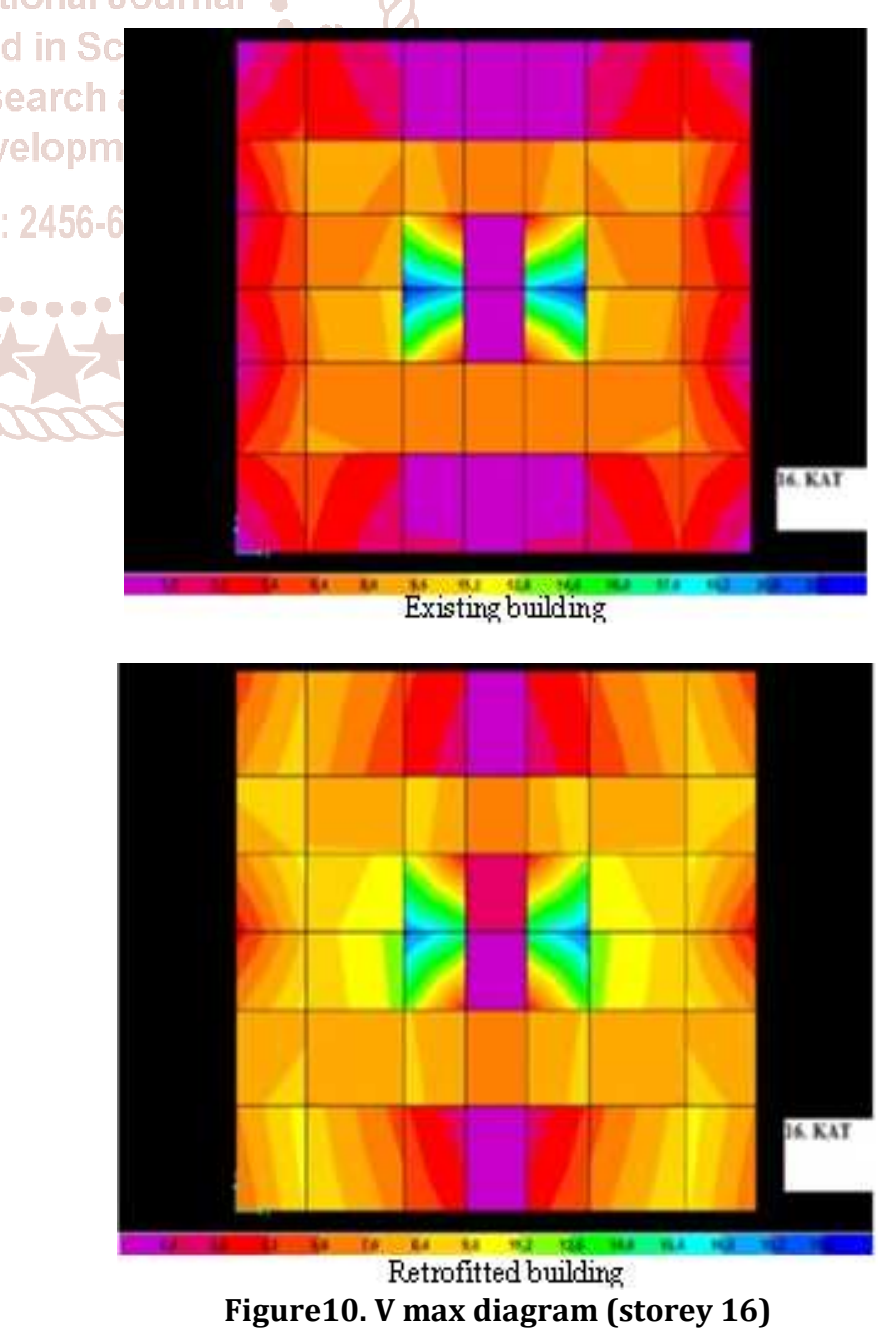

Figure10. V max diagram (storey 16) 
The Period, Frequency, M max-min and V max-min values for existing and retrofitted building were given in the table below.

Table 3. The Comparisons of Existing Building and Retrofitted Building

\begin{tabular}{|c|c|c|}
\hline & $\begin{array}{c}\text { Existing } \\
\text { Building }\end{array}$ & $\begin{array}{c}\text { Retrofitted } \\
\text { Building }\end{array}$ \\
\hline Period (sec) & 1.6549 & 1.1967 \\
\hline Frequency (cyc/sec) & 0.6042 & 0.8356 \\
\hline $\mathrm{V} M A X\left(\mathrm{~N} / \mathrm{mm}^{2}\right)$ & 23.217 & 20.936 \\
\hline $\mathrm{V} \min \left(\mathrm{N} / \mathrm{mm}^{2}\right)$ & 2.73 & 9.05 \\
\hline $\mathrm{M} \max (\mathrm{Nm})$ & 18.12 & 12.694 \\
\hline $\mathrm{M} \min (\mathrm{Nm})$ & 22.743 & 1.64 \\
\hline
\end{tabular}

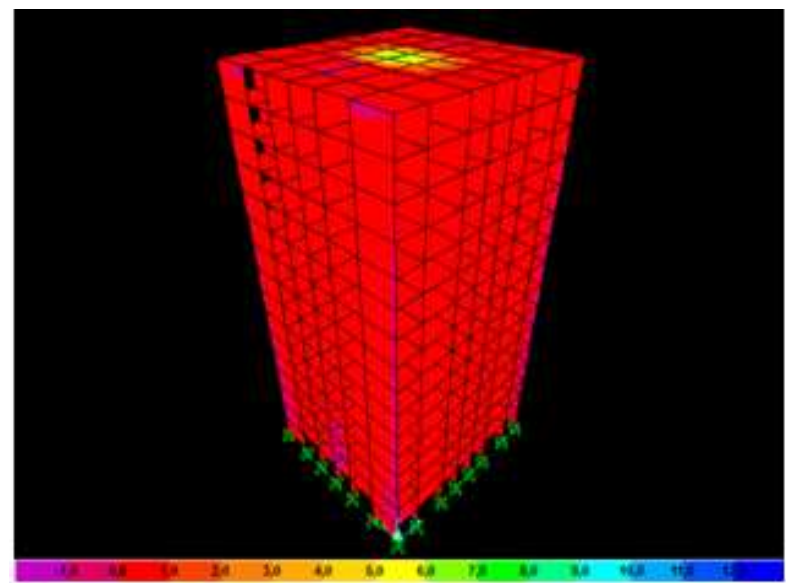

Figure11. Retrofitted building (MMax)

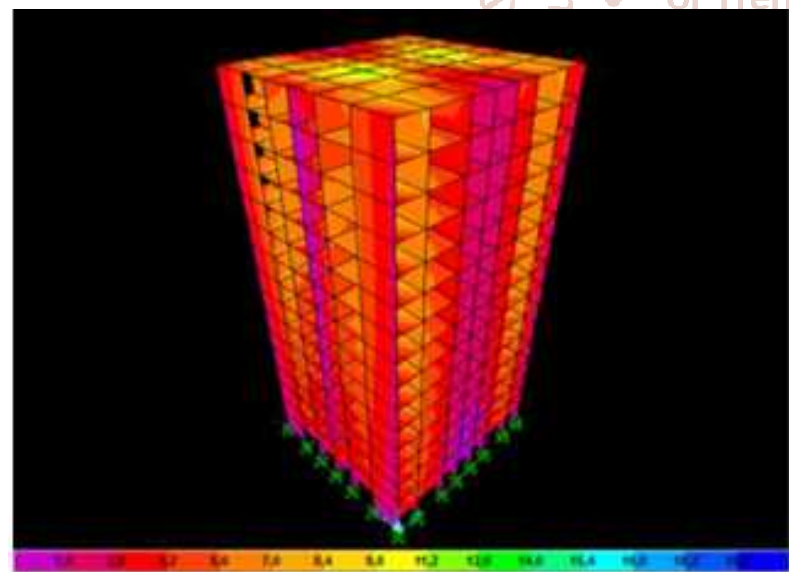

Figure12. Retrofitted building (Vmax)

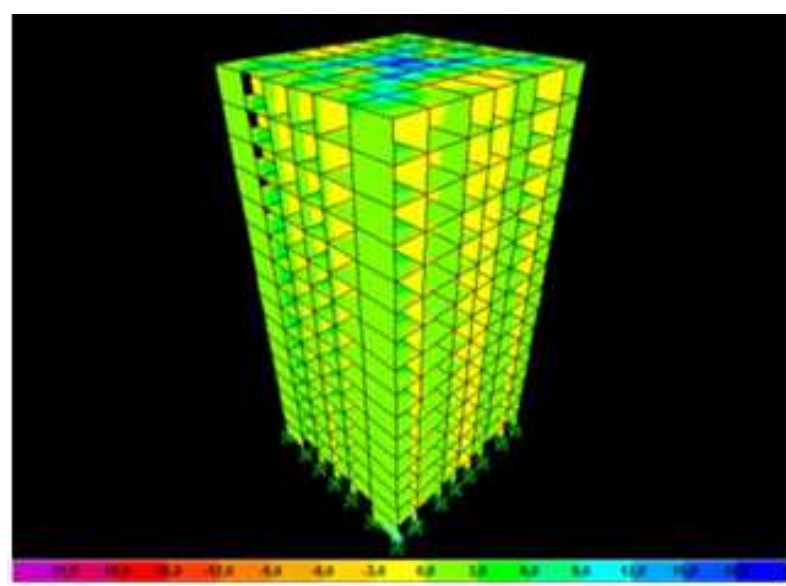

Figure13. Existing building (MMax)

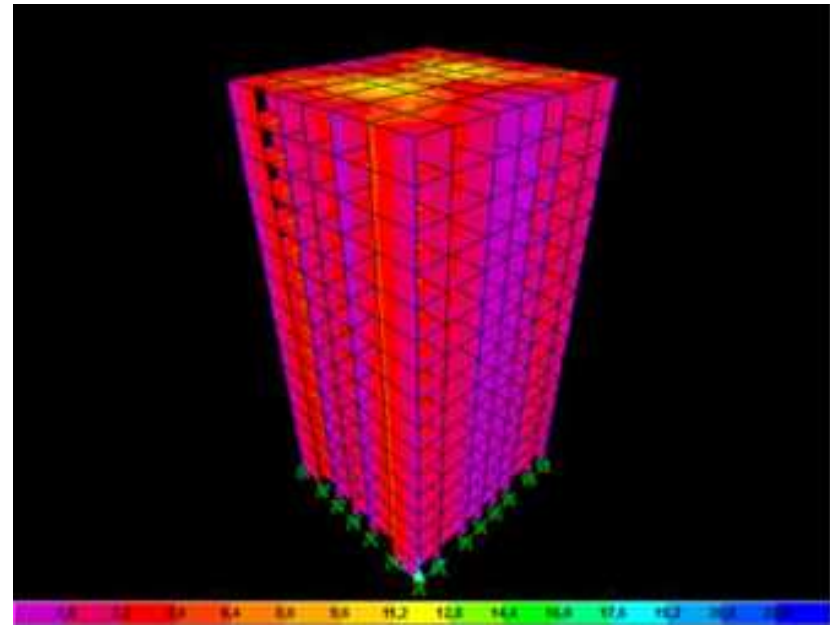

Figure14. Existing building (VMax)

\section{Conclusions}

In this study, the effectiveness of using CFRP in masonry buildings for the sake of improving stiffness and reducing stresses has been investigated. A two storey building was analyzed to examine its responses with and without CFRP. When strengthened by CFRP bonded to its interior walls and tension side of its slabs, the studied building showed a remarkable effectiveness for the use of Carbon Fiber Reinforced Polymers, where its stiffness was increased by around $48 \%$ (when applied to walls only) compared to the stiffness of the same building but without CFRP. The period of existing building was 1.65 and the period of the retrofitted building is 1.19. It provides increase of structure stiffness about $86.45 \%$ for the retrofitted building. Therefore, it was generally shown that the use of CFRP results in stresses which are much smaller than stresses resulted from non- strengthened building; whereas stiffness increase may depend on which part of the building CFRP is applied. The conclusion of this study strongly suggests that the strengthening of masonry building structures, especially in retrofitting and/or rehabilitation, should be very efficient in substantial reduction of stresses, increase in stiffness and natural frequencies, thus leading to a durable, crack free and sustainable structure.

\section{References}

[1] G. Eason, B. Noble, and I. N. Sneddon, "On certain integrals of Lipschitz-Hankel type involving products of Bessel functions," Phil. Trans. Roy. Soc. London, vol. A247, pp. 529- 551, April 1955. (references)

[2] Yang, Y., Xue, Y., Yu, Y., Liu, R. and Ke, S., "Study of the design and mechanical performance of a GFRPconcrete composite deck", Steel and Composite Structures, vol. 24, pp. 679-688, 2017.

[3] Keykha, A. H., "Numerical investigation on the behavior of SHS steel frames strengthened using CFRP", Steel and Composite Structures, vol. 24, pp. 561-568, 2017.

[4] Smyrou, E., Karantzikis, M. and Bal, İ. E., "FRP versus traditional strengthening on a typical mid-rise Turkish RC building", Earthquakes and Structures, vol. 9, pp. 1069-1089, 2015.

[5] Elwan, S. K. and Omar, M. A., "Experimental behavior of eccentrically loaded RC slender columns strengthened using GFRP wrapping", Steel and Composite Structures, vol. 17, pp. 271-285, 2014 
International Journal of Trend in Scientific Research and Development (IJTSRD) @ www.ijtsrd.com eISSN: 2456-6470

[6] Kasimzade, A.A. and Tuhta S., "Analytical, numerical and experimental examination of reinforced composites beams covered with carbon fiber reinforced plastic", Journal of Theoretical and Applied Mechanics, vol. 42, pp. 55-70, 2012.

[7] Kasimzade, A.A. and Tuhta, S., "OMA of model steel structure retrofitted with CFRP using earthquake simulator", Earthquakes and Structures, vol. 12, pp. 689-697, 2017.
[8] Kasimzade, A.A. and Tuhta, S., "Finite Element, Analytical, Experimental Investigation of Reinforced Concrete Beams Strengthened with CFRP and Related Structure Analysis Problem's Solutions", AACEU, Scientific Works No 2, pp.18-26, 2005.

[9] Kasimzade, A.A. and Tuhta, S., "Performance of Reinforced Concrete Columns Confined by Composite Wraps", AACEU, Scientific Works No 2, pp. 13-18, 2005

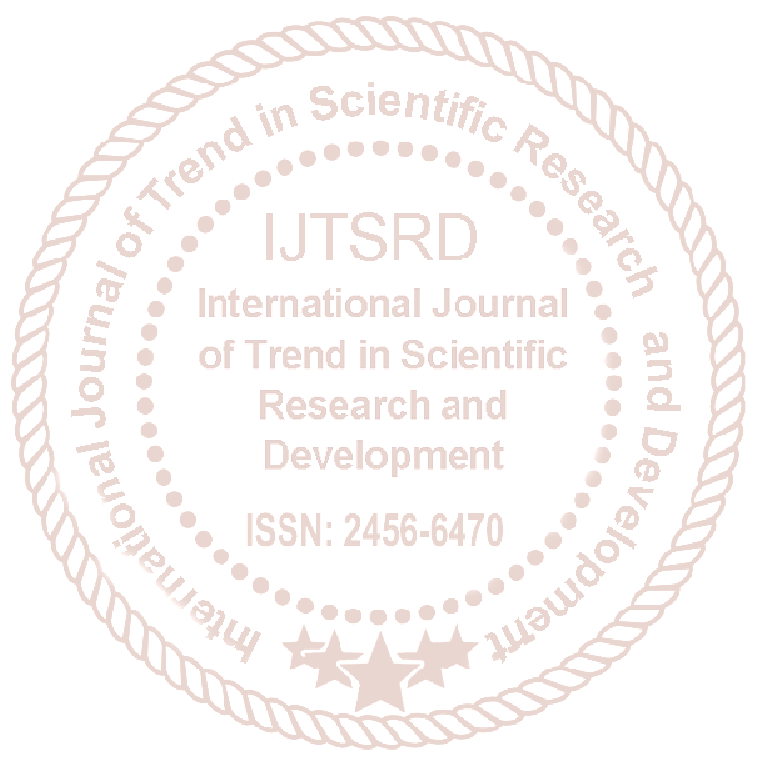

